УДК 336.71(477)(045)

DOI: 10.31339/2617-0833-2019-2(27)-185-191

ОЦІНКА ВПЛИВУ ДЕРЖАВНОГО РЕГУЛЮВАННЯ НА ДІЯЛЬНІСТЬ БАНКІВСЬКОГО СЕКТОРУ УКРАЇНИ

Кузьма Н. М., Лінтур I. В.

\title{
ASSESSMENT OF THE IMPACT OF STATE REGULATION ON THE ACTIVITIES OF THE BANKING SECTOR OF UKRAINE
}

Kuzma Natalia, Lintur Inna

У статті досліджено результативність діяльності банківського сектору України за останні 5 років та здійснено оцінку впливу державного втручання та регулювання на функціонування кожного банку окремо та банківської системи в цілому. Виявлено чинники, які відіграють найбільш важливу роль у тому, прибутковим чи збитковим буде річний підсумок діяльності банку, а так же сформовано основні завдання, які покладаються на державу та ї̈ законодавство у спектрі регулювання банківської системи Украӥни.

Незважаючи на значні здобутки в дослідженні питань оптимальної побудови системи банківського регулювання і механізмів державного нагляду з інституційної точки зору, ще не знайдено єдиного погляду в теорії і практиці як в Украӥні, так $i$ у розвинутих зарубіжних країнах оптимальних підходів щэодо організачійної побудови механізмів регулювання фінансової та банківської діяльності, а також нагляду. Дискусійними залишаються окремі аспекти наглядово-регулятивної діяльності Національного банку Украӥни.

Ключові слова: банк, банківська система, банківський контроль, банківський нагляд, державне регулювання, саморегулячія.

The article investigates the performance of the banking sector of Ukraine over the past 5 years and assesses the impact of government intervention and regulation on the functioning of each bank separately and the banking system as a whole. The factors that play the most important role in the profit or loss of the annual activity of the bank are identified, as well as the main tasks that are entrusted to the state and its legislation in the spectrum of regulation of the banking system of Ukraine.

Despite significant advances in the study of optimal banking regulation and institutional oversight mechanisms, no unified view has been found in theory and practice in both Ukraine and developed foreign countries of optimal approaches to the organizational construction of financial and banking regulatory mechanisms. activities and supervision. Some aspects of the oversight and regulatory activity of the National Bank of Ukraine remain debatable.

Key words: bank, banking system, banking control, banking supervision, state regulation, self-regulation.

Сучасні реалії ринку (інтернаціоналізація, трансформація глобального банківського сектору, розширення меж діяльності, активізація інвестиційної діяльності, лібералізація руху іноземного капіталу, диверсифікація лідерських позицій банківської діяльності, концентрація міжнародного банківського капіталу) ставлять перед банківськими системами вимоги щодо стійкості, конкурентоспроможності, спроможності інтегруватися у світовий простір. Інтеграція у світовий фінансовий простір вимагає вдосконалення системи законодавчого регулювання банківської діяльності. Саме тому, дослідження впливу державного регулювання на діяльність банківського сектору України є актуальним та необхідним.

Сфера адміністративного регулювання банківської діяльності в Україні постійно була об'єктом досліджень вітчизняних вчених. Зокрема, іiї дослідженням займались I. I. Д’яконова, Б. П. Адамик, О. І. Хабюк, М. В. Плотнікова, В. В. Коваленко та інші. В розрізі 
державного регулювання здійснювалось дослідження і окремих форм адміністративного регулювання - реєстрація та ліквідація банків, застосування санкцій, однак комплексного фінансово-правового дослідження адміністративного регулювання банківської діяльності не здійснювалось. Як наслідок, необгрунтовано мало уваги приділяється дослідженню таких форм адміністративного регулювання як надання рекомендацій банкам, нагляд за діяльністю банків, взаємозв'язок усіх форм адміністративного регулювання.

Аналіз українського законодавства та праць вчених показав, що єдиного підходу до визначення поняття «державного регулювання банківської системи» сьогодні немає.

Державне регулювання у наукових підходах вчених визначається як економічний метод державного управління, який $\epsilon$ системою типових заходів законодавчого i контролюючого характеру, що здійснюються відповідними державними органами та громадськими організаціями з метою стабілізації а пристосування існуючої системи до умов, що постійно змінюються.

У ст. 66 Закону України «Про банки і банківську діяльність» встановлено, що Національний банк України (далі - НБУ) здійснює державне регулювання діяльності банків у формі адміністративного та індикативного регулювання.[3] Водночас, в нормах Закону України «Про Національний банк України» визначена основна мета банківського регулювання - забезпечення безпеки та фінансової стабільності банківської системи; захист інтересів вкладників і кредиторів [6].

Стабільність банківської системи буде досягнута за умови чіткого визначення завдання банківського регулювання органами банківського нагляду. Саме правильно поставлені завдання та розроблена регулююча політика держави забезпечать стабільне функціонування банківської системи, ефективний розвиток національної економіки та підвищення рейтингів українських банків на світових фінансових ринках. Регулювання банківської діяльності необхідне на будь-якому етапі розвитку економічних відносин і на сьогоднішній день є невід'ємною складовою державної політики.

Таким чином, першочерговим завданням регулювання банківської діяльності на державному рівні $є$ забезпечення конкурентоспроможності банківських установ як основних провідників монетарної політики, інститутів акумулювання i перерозподілу фінансових ресурсів, тобто сучасна система регулювання повинна забезпечувати стійку рівновагу, надійність і ліквідність банків, що відповідає цілям грошово-кредитної політики і стимулює економічне зростання країни.

Сутність державного регулювання банківської діяльності визначається тим, наскільки ефективно держава реалізує свої функції. Від того, наскільки адекватно система державного регулювання реалізуватиме функції координації у банківському секторі, залежатиме розвиток банківського бізнесу та подальше економічне зростання у вітчизняній економіці.

Регулювання банківської сфери в Україні можна класифікувати за декількома ознаками. Таким чином, за характером впливу на банки можна виділити такі два види регулювання банківської діяльності: саморегуляція через ринковий механізм і державне регулювання. Згідно з теорією саморегуляції через ринковий механізм ("free banking"), розвиток, контроль та безпека банківської системи можливі і без регулювання з боку держави[5]. Різновид ринкового саморегулювання, як і будь-який інший елемент економік, має певний ряд переваг і недоліків, але в сучасних умовах більшість країн не обходиться без державного регулювання банківської системи, однак, можна стверджувати й те, що ефективно організований державний контроль повинен органічно доповнюватися саморегуляцією, внутрішнім контролем.

У загальному вигляді поняття “державне регулювання" можна визначити як економічний метод державного управління, який є системою типових заходів законодавчого й контрольного характеру, що здійснюються відповідними державними органами та громадськими організаціями 3 метою стабілізації й пристосування існуючої соціально- 
економічної системи до умов, що постійно змінюються [4].

Що стосується банківського нагляду, то Національним банком України налагоджена система щоденного контролю показників діяльності комерційних банків, є певна практика взаємовідносин між банківським сектором і регулятором - Національного банку України, створено належну матеріально технічну базу, є необхідний штат професійних працівників в системі Національного банку України [7]. Тобто, створено всі необхідні передумови i можливості для здійснення ефективного нагляду за банківським сектором.

Разом із тим державне регулювання банківської системи є поняття значно ширшим, ніж просто регулювання діяльності комерційних банків. А тому його механізм повинен включати певні органи, які розмежовуються за напрямками застосування (рис. 1).

Механізми державного регулювання банківської сфери

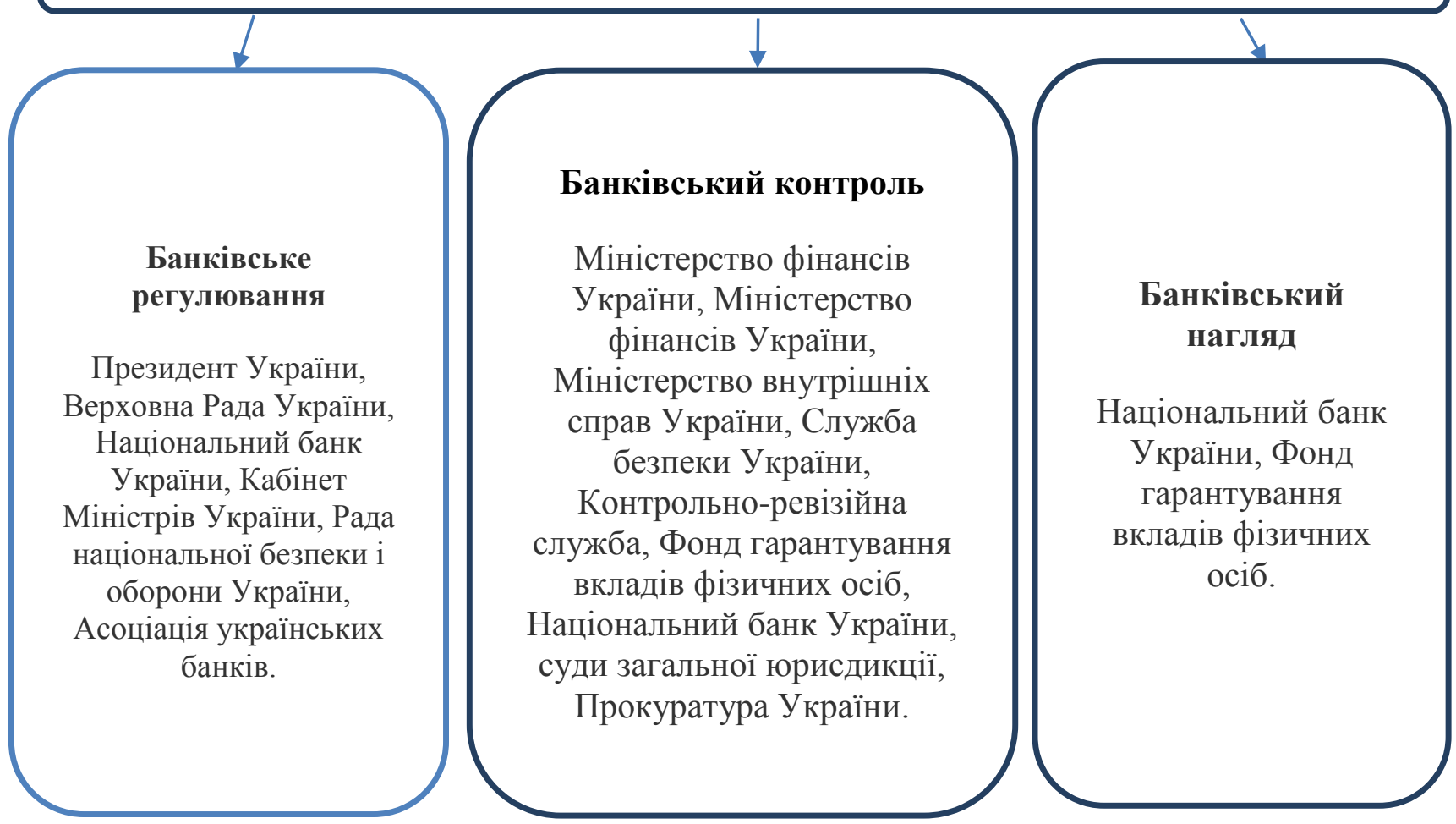

Рис.1 Органи державного регулювання банківської системи України

Враховуючи досвід державного регулювання і нагляду за діяльністю інститутів кредитної системи в Україні, доцільним $є$ розробка і поетапна реалізація заходів щодо створення єдиного органу регулювання і нагляду на базі діючої системи регулювання та нагляду Національного банку України. Питання вдосконалення системи регулювання i нагляду в напрямку створення банківської системи регулювання і нагляду за діяльністю фінансових посередників $є$ актуальним, проте змінювати систему організації банківського нагляду на теперішньому етапі, на наш погляд, - справа доволі ризикована і може призвести до негативних наслідків. Варто також враховувати вітчизняний досвід у зазначеній сфері, переваги і недоліки існуючих механізмів державного регулювання банківської системи, а також розвивати перспективні напрямки державного регулювання в нашій державі у зазначеній сфері.

Інструменти регулювання банківської діяльності в широкому розумінні можливо поділити на дві групи: інструменти монетарного регулювання та інструменти банківського регулювання. Не зважаючи на їх тісний зв'язок, кожну з цих груп інструментів можна розглядати окремо. До інструментів саме другої групи, насамперед, відноситься процедура допуску банків на ринки, встановлення та контроль за дотриманням обов'язкових економічних нормативів, встановлення норм резервування та операції центрального банку 3 
рефінансування. Зрозуміло, що досить важко визначити чітку межу між монетарними та наглядовими інструментами, бо вони пов'язані і певним чином впливають один на одного[2].

НБУ визначає банківський ризик за його впливом на капітал і надходження. Ризик це ймовірність того, що події, очікувані або неочікувані, можуть мати негативний вплив на капітал та/або надходження банку [3].

Для розгляду ризиків потрібно вирішити, чи $є$ ризики, які бере на себе банк, виправданими. Ризики вважаються виправданими, якщо вони $\epsilon$ зрозумілими, контрольованими, такими, що можна виміряти, й такі, що відповідають здатності банку швидко реагувати на негативні чинники. Якщо ризики є невиправданими, наглядовці мають взаємодіяти 3 керівництвом і спостережною радою банку і спонукати їх до пом'якшення або усунення цих невиправданих ризиків. Ринкові умови і структури банків є різними. Єдиної системи управління ризиками, яка була б прийнятною для всіх банків, не існує. Кожна установа має розробити власну програму та системи управління ризиками відповідно до своїх умов та потреб. Ефективні системи управління ризиками мають бути незалежними від діяльності, пов'язаної з прийняттям ризиків. Кожна система управління ризиками має включати елементи: виявлення ризику, вимірювання ризику, контроль ризику та моніторинг ризику.

Суттєвими чинниками ефективного управління ризиками є високий професійний рівень керівництва і відповідна комплектація персоналом. Керівництво банку несе відповідальність за впровадження, надійність і забезпечення функціонування систем управління ризиками.

До обов’язків керівництва банку належать такі [1]:

- реалізовувати стратегічний напрям розвитку банку;

- розробляти положення, формальні або неформальні, що визначають толерантність банку до ризику та відповідають стратегічним цілям банку;

- наглядати за розробленням і забезпеченням функціонування інформаційних систем управління з метою забезпечення їх своєчасності;

- точності та інформативності.

Сучасна економічна ситуація в Україні та світі потребує нових критеріїв оцінки ризиків банками. Вона полягає в новому розумінні структури і складових ризиків. Під час розробки власної системи управління ризиками банк повинен спиратися на міжнародний досвід та основні інновації у забезпеченні фінансової безпеки. 3 огляду на це для оцінки ризикованості банківської діяльності пропонується використовувати рекомендації МВФ, ФАТФ та новий варіант Базельської угоди (Базель II). За новою Базельською угодою за основні види прийняті ринковий, кредитний та операційний ризики; інші види ризиків вважаються такими, що входять до складу цих трьох основних. Однак банківська діяльність на Україні, як і в будь-якій державі, має свою специфіку [6].

Налагодженість державної системи контролю та регулювання неабияк відзначається на результативності діяльності як банківської системи загалом, так і на прибутковості кожного банку окремо.

Так, у січні-вересні 2019 року платоспроможні банки отримали 48,35 млрд грн чистого прибутку, що в 4,4 рази більше, ніж за аналогічний період минулого року. За підсумками трьох кварталів 2018 року банківська система отримала чистий прибуток у розмірі 10,9 млрд грн.

Загалом доходи банків за дев'ять місяців поточного року зросли на 28\% до 184 млрд грн, витрати - на 2\% до 135,6 млрд грн.

Високу динаміку доходів банків визначило зростання чистих процентного та комісійного доходів банків - на 18\% до 59,5 млрд грн та на $14 \%$ до 32,3 млрд грн відповідно завдяки стрімкому розвитку споживчого кредитування та безготівкових операцій із населенням.

Крім того, високі показники сектору зумовлені суттєвим прибутком від торгових 
операцій державних банків, зокрема від валютної переоцінки. Загалом позитивний результат усіх банків від переоцінки та від операцій купівлі-продажу склав 14,8 млрд грн, за аналогічний період 2018 року він мав від'ємне значення (-2,2 млрд грн). До того ж обсяг відрахувань банками у резерви скоротився у 2,4 рази - 3 19,9 млрд грн за 9 місяців 2018 року до 8,3 млрд грн за 9 місяців 2019 року.

"Розпочатий Національним банком цикл зниження ставок позитивно впливатиме на прибутковість банків. За відсутності інформаційних та юридичних атак на банки вартість фондування знижується, а високий попит на кредити з боку населення забезпечує високу прибутковість у роздрібному сегменті. Темпи зростання депозитів залишаються достатніми для підтримки кредитування. Загалом ми очікуємо, що в середньостроковій перспективі прибутковість банків дещо послабиться, але залишатиметься на достатньому рівні для збереження інтересу 3 боку інвесторів", - зазначила Перший заступник Голови Національного банку Катерина Рожкова.

Водночас у січні-вересні зменшилася кількість та частка збиткових банків. Так, із 76 платоспроможних банків станом на 1 жовтня 2019 року 66 банків були прибутковими та отримали чистий прибуток 49,6 млрд грн, що перекрило збитки 10 банків на загальну суму 1,3 млрд грн. Нагадаємо, що за підсумком 2018 року збитковими були 14 із 77 діючих на той момент банків.

\section{Результати діяльності банківської системи України за 2013-2018 pp.}

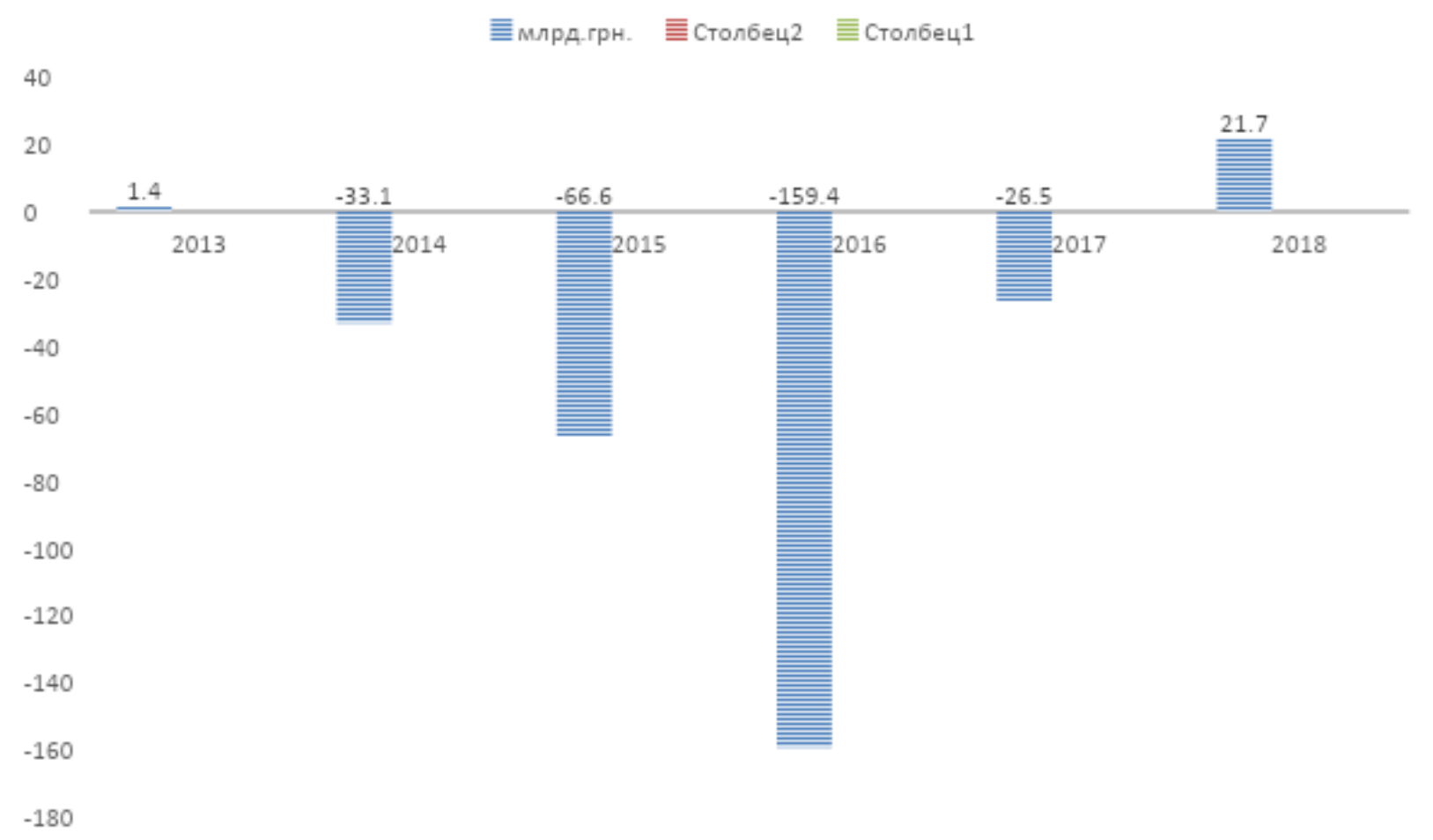

Рис 2. Результати діяльності банківської системи України за 2013-2018 рр.

Тож, як прослідковується на рис 2, після збиткових для банківської системи 20142017 років, фінансовий результат банків за 2018 рік в 21,7 млрд грн є найбільшим на історичному горизонті. Він став можливим за рахунок активізації банками кредитування, насамперед роздрібного гривневого на понад $30 \%$ у річному обчисленні. Також збільшенню прибутку банківського сектору сприяло зниження банками відсоткових ставок за вкладами громадян упродовж більшої частини року і значне зменшення обсягів формування резервів, що демонструє пророблену банками роботу 3 адекватного оцінювання активів та відповідного формування резервів у попередні роки. Як показують результати діяльності 
банківського сектору України за січень-вересень 2019 року, цей рік також стане успішним для банків в частині прибутковості, оскільки обсяги кредитування продовжать зростати.

На основі проведеного дослідження українського законодавства та підходів до визначення поняття «державне регулювання банківської діяльності» запропоноване єдине значення цього терміну як системи важелів впливу держави на банківський сектор, яка через засоби (інструменти, форми, методи) забезпечує досягнення єдиної мети - ефективне функціонування фінансового сектору економіки України.

Проаналізувавши значення державних важелів впливу на результати діяльності банків України можна говорити про те, що трансформаційні перетворення в нашій державі ускладнюють процес забезпечення ефективного та стабільного функціонування банківської системи i потребують відповідних механізмів регулювання. Головними напрямами забезпечення ефективного та стабільного функціонування сучасної банківської системи $\epsilon$ надійна та стійка макроекономічна політика, належним чином розвинена система формування політики фінансової стабільності, добре розвинута державна інфраструктура, чіткі принципи управління кризою, відновлення роботи 3 проблемними установами, належний рівень системного захисту, ефективна ринкова дисципліна.

\section{Список використаних джерел}

1. Асоціація українських банків [Електронний ресурс]. - Режим доступу: http://www.aub.com.ua.

2. Закон України "Про банки і банківську діяльність" від 1 січня 2019 року № 2121 - XIV // Законодавчі і нормативні акти з банківської діяльності. - № 1.

3. Основні засади грошово-кредитної політики на 2013 рік. Схвалено рішенням Ради НБУ від 05.09.2012 p, № 16 [Електронний ресурс]. - Режим доступу : http://www.bank.gov.ua.

4. Про затвердження Положення про Державну службу фінансового моніторингу України : Постанова Кабінету Міністрів України від 29.07.2015 № 537 // Офіційний вісник України. - 2014. -- № 77.

5. Про регулювання грошово-кредитного ринку [Електронний ресурс]. - Режим доступу : http://www.bank.gov.ua.

6. Стукало Н. Державне антикризове регулювання банківського сектору: досвід СС та України / Н. Стукало, М. Литвин // Вісник НБУ. - 2010. - № 7.

7. Чуб О. Банківські кризи у глобальному середовищі / О. Чуб // Банківська справа. 2011. - №1.

\section{References}

1. Asotsiatsiya ukrayins'kykh bankiv [Association of Ukrainian Banks]. http://www.aub.com.ua.

2. "Zakon Ukrayiny "Pro banky i bankivs'ku diyal'nist"” vid 1 sichnya 2019 roku № 2121 XIV [Law of Ukraine "On Banks and Banking" of January 1, 2019 № 2121 - XIV].” Legislative and regulatory acts on banking 1.

3. Osnovni zasady hroshovo-kredytnoyi polityky na 2013 rik. Skhvaleno rishennyam Rady NBU vid 05.09.2012 r, № 16 [The main principles of monetary policy for 2013. Approved by the decision of the NBU Council of 05.09.2012, № 16]. http://www.bank.gov.ua.

4. Pro zatverdzhennya Polozhennya pro Derzhavnu sluzhbu finansovoho monitorynhu Ukrayiny : Postanova Kabinetu Ministriv Ukrayiny vid 29.07.2015 № 537 [On approval of the Regulation on the State Financial Monitoring Service of Ukraine: Resolution of the Cabinet of Ministers of Ukraine dated 29.07.2015 No. 537]. 2014. Official Bulletin of Ukraine 77.

5. Pro rehulyuvannya hroshovo-kredytnoho rynku [On the regulation of the monetary market]. http://www.bank.gov.ua. 
6. Stukalo, N. and M. Lytvyn 2010. Derzhavne antykryzove rehulyuvannya bankivs'koho sektoru: dosvid YeS ta Ukrayiny [State anti-crisis regulation of the banking sector: experience of the EU and Ukraine]. Bulletin of the National Bank of Ukraine 7.

7. Chub, O. 2011. Bankivs'ki kryzy u hlobal'nomu seredovyshchi [Banking crises in the global environment]. Banking, 1.

УДК 658.14:330.146(045)

DOI: 10.31339/2617-0833-2019-2(27)-191-194

\author{
КАПІТАЛІЗАЦЇ̈ ПІДПРИСМСТВА - СУТНІСТЬ ТА ФУНКЦЇ̈ \\ Нестерова С.В., Обіцький А.А.
}

\title{
ESSENCE AND FUNCTIONS OF ENTERPRISE CAPITALIZATION
}

Nesterova Svitlana, Obitskyi Anatolij

Поняття капіталізації в економічній літературі розглядається з різних точок зору: як процес $і$ як результат. Крім того, відрізняють капіталізацію економіки, регіону і суб'єкта господарювання. Метою статті було охарактеризувати капіталізацію на рівні підприємства, як мікроекономічний індикатор успішності функиіонування.

На основі методу порівняльного аналізу запропоновано визначення: капіталізація підприємства - це інтегральна оцінка його вартості, щзо базується на обліку актуальних кількісних і якісних параметрів його господарського та фінансового стану. Дане визначення підкріплено функиіями, які виконує капіталізація підприємства в сучасній бізнес-середовищі: прогнозна, мобілізачійна, розподільна, стратегічна, стимулююча і інформаційна.

Ключові слова: капіталізачія, капіталізація підприємств, максимізація прибутку, розвиток.

The concept of capitalization in economic literature is considered from different points of view: As a process and as a result. In addition, the capitalization of the economy, the region and the subject of management is distinguished. The purpose of the article was to characterize capitalization at the enterprise level as a microeconomic indicator of success of operation. Based on the method of comparative analysis, a definition is proposed: The capitalization of the enterprise is an integral estimate of its value, based on the account of the actual quantitative and qualitative parameters of its economic and financial condition. This definition is supported by the functions that perform the capitalization of the enterprise in the modern business environment: Forecasting, mobilization, distribution, strategic, stimulating and information.

Key words: capitalization, enterprise capitalization, profit maximization, development.

Капіталізація суб'єкта економіки є одним із найважливіших фінансових індикаторів результативності функціонування. Рівень капіталізації сигналізує про розвиток економік, регіонів, окремих господарських одиниць.

Дослідження змісту, методів оцінки та значення капіталізації є предметом уваги низки науковців, як в Україні, так і закордоном. При цьому спостерігається різноманітність тлумачення терміну залежно від рівня застосування (макро-, мезо-, мікро-) та об'єкта, щодо якого розглядається дане поняття.

Так, група дослідників (Амосов О.Ю., Гавкалова Н.Л. [1], Горячук В.Ф. [3] та інші) проблеми підвищення капіталізації висвітлюють в площині макроекономічного фактору. На рівні регіону, впроваджуючи поняття «регіональна капіталізація», науковці - Пушкарчук I.M. [8], Музика I.C. [7] окреслюють чинники, що дозволяють оцінити потенціал територіального розвитку економіки. Мамонтова Н.А. [6] та Турило А.А. [9] висвітлюють капіталізацію 3 